\title{
A theoretical and methodological framework for the analysis and measurement of environmental heritage at local level
}

\author{
G. Fabiola Safonte ${ }^{\mathrm{a}}$, Ferdinando Trapani ${ }^{\mathrm{b}}$ * \\ IRPAIS, Istituto di Ricerca e Promozione delle Aree Interne delle Sicilia \\ Università degli Studi di Palermo, Dipartimento di Architettura, Viale delle Scienze, 90128 Palermo, Italy
}

\begin{abstract}
The study aims to assess the lived experience and the environmental heritage perceived level by residents of an high complexity rural area, and which is, in this context, the role played by production of renewable energies. The paper introduces the concept of rural capital as an effective tool for environmental heritage analysis and measurement. The proposed theoretical and methodological approach allows, in fact, its analysis in order to understand what dimensions related to territoriality are connected to the perceived level of environmental heritage at local level. Translated into operational terms, the methodology has resulted in an empirical analysis of a rural and inner area of Sicily, performed both through the examination of identified benchmark indicators, and through the observation of various phenomena, directly experienced by rural residents, detected by sample surveys that, by using a complex sampling design, allow more accurate estimates, modelled on the contexts. All these results are integrated by a multi-case study carried out by a qualitative survey detected both through desk analysis and in field observation, and through in-depth interviews with stakeholders and focus groups with local actors, all asked to assess in a participative way. The research proves that it is necessary to activate the processes of participation and social learning in order to energy planning of the territorial system, allowing at the same time to protect, preserve and enhance the environmental and natural heritage.
\end{abstract}

(C) 2017 The Authors. Published by Elsevier B.V.

Peer-review under responsibility of the organizing committee of AREQ 2017.

Keywords: Local sustainability, renewable energies, territory, environmental heritage, territorialist planning approach.. Attributions: The paper is the result of joint work of the authors. However, Fabiola Safonte oversaw the Par. 2, 3 and 4; Ferdinando Trapani oversaw Par. 5. Par. 1 and 6 was edited by both the authors.

\footnotetext{
* Corresponding author: Ferdinando Trapani Mob.: +39 3345001155

E-mail address: ferdinando.trapani@unipa.it; trapanif@gmail.com.
} 


\section{Introduction}

Within the debate on sustainable development, the energy issue certainly occupies an increasingly important role, because the questions related to the production, distribution and consumption of non-renewable energy sources are among the main causes of unsustainability at different levels governance $\mathrm{e}^{1,2,3}$.

In this context, the issue calls into question, on the one hand, the relationship between energy and territories and, on the other, the relationship between the different geographical scales within which the local dimension certainly plays an active role $e^{4,5,6}$.

A sustainable energy model requires in fact an articulated territorial reorganization, based on the decentralization of production and consumption of energy and the use of renewable energy sources spatially and locally spread through a place-based approach ${ }^{7,8,9}$.

In literature, several authors believe this approach an effective level of governance for sustainability and environmental issues, since the objectives, strategies and policy actions should be implemented locally. The aim is to achieve a contextual understanding of the issues and establish effective and efficient forms of regulation and management, also through the introduction of participatory and inclusive governance practices of many local actors involved in the management of energetic and environmental emergencies ${ }^{10,5}$. On the other hand, the interdependence between the energetic and the territorial systems is so deep that it is not possible to imagine a transformation of the first without affecting the seconds, and vice versa ${ }^{11}$.

In this context, if, on the one hand, in the literature were developed several studies in urban / metropolitan areas about the optimization of the relationship between city and new technologies in order to increase efficiency - also in view of the potential for smart energy savings ${ }^{12}$ and of the impact on social co-creative ecosystems ${ }^{13}-$ on the other hand, for rural areas, focused on the primary sector and in the economic and social decline, problematically emerges the prospect of de-growth which poses problems sharing ${ }^{14}$.

Alternatively, both in the academic field and in the field of design, the territorial aspects on the current energy transition not yet receiving the necessary attention. It seems therefore necessary to find a tool that allows to hold together the spatial, social, geographical and historical aspects energy-related.

The study, starting from the collection of empirical evidence provided by the analysis of the territorial environmental heritage at the local level - which in particular is consisting of all natural elements that are not created by human but rather represent an unlimited gift of nature and the result of the interaction between man and nature itself, represented for example by the utilized agricultural area or by the landscape - and through the application of an analytical model based on the examination of rural capital, shows that it is necessary to activate the processes of participation and social learning in order to energy planning of the territorial system, allowing at the same time to protect, preserve and enhance the environmental and natural heritage. These processes enable convenience from an economic point of view, since they generate income; from an environmental point of view, since they promote the conservation and protection of natural heritage; from a social point of view since they generate employment growth, as well as the strengthening of territorial identity and sense of belonging to a place.

\section{2. Theoretical framework}

In literature, within the debate on the role of the local dimension in relation to sustainability, the attention towards the rural specificities focuses on those that are defined as repertoires of development, i.e. the sum of the resources and the characteristics associated with a territory, and that, the territorialist literature identifies, instead, as territorial mass, with qualitative and quantitative traits, made by the historical accumulation of territorialization $\operatorname{acts}^{15}$.

The element that distinguishes these settings, as well as the approach of sustainable livelihood ${ }^{16,17}$, is the interest focused on accessibility to resources which refers to the capabilities approach of Sen ${ }^{18,19}$. In this literature, the crucial question is given, on the one hand, by the awareness of local actors about the allocation of local resources and, on the other, by the relationship between the different local actors, in terms of networks which determine the real access to the available resources ${ }^{20,21,22,23,24,25,26}$. The use of the term network is a metaphor to analyze and to interpret the processes and the activities that take place in rural $\operatorname{areas}^{27,28,29}$. 
In this perspective, the analysis of territory, which is essential for an active description of the environmental and territorial heritage, must be aimed to the understanding of the rules of environmental knowledge, of the processes that gave rise to the type and personality of the place and of relational and co-evolutionary systems among physical environment, built environment and anthropic environment, interpreted in their co-evolutionary relations, the result of a historical, anthropological and social process of identity construction, which involves both internal and external mechanisms of definition. Since the territory is the result of a relational process temporally located between these components, spatial analysis must necessarily make use of special analytical operational methods ${ }^{15,30}$.

To this end, several studies use the concept of territorial capital $31,32,33,34,35$ the set of local resources that can be mobilized to create value, broken down into further sub-dimensions (economic, human and labor market, social, institutional, environmental, cultural and symbolic) ${ }^{6,37,38,39,40}$, each of which is used in the production process to increase the amount of capital itself $\mathrm{f}^{28,29,41,42}$.

However, since the measurement unit of the territorial capital can't be independent by the nature of the processes that itself contains, it follows that the territorial capital of a rural area will have to be assessed with a metric other than that which would apply to the analysis of capital of urban and / or urbanized contexts ${ }^{15}$.

The concept of rural capital allows to overcome this limitation; it is, in fact, the set of dimensions that involve the combination of components and of the tangible and intangible peculiarities of the territorial context that make up the total assets ${ }^{15}$.

In literature some attempts can be traced to conceptualize, none of which seems to follow our approach. A similar term, "countryside capital", is used for the first time since the United Kingdom Countryside Agency ${ }^{43}$, which gives a first definition in terms of "the fabric of the countryside, its villages and its market towns" ${ }^{43}$. According to Garrod" its intangible dimensions concern rural villages and country towns, considered the functional elements of the rural economy as well as the Heritage Village Shopping ${ }^{45}$. Other features are discussed in detail by Garrod ${ }^{44}$, and more recently, by the Americans McClinchey and Carmichael ${ }^{46}$.

The rural area under study has its own strong identity that is actively involved in the individual and collective existence: in the cognitive, linguistic, perceptual, sensorial processes. According to this approach, it is clear that we should not report to rural area as a uniform and undifferentiated space that can be treated with generalized models, through the use of simplified variables and purely statistical and quantitative procedures and that, from the analytical point of view, the rural capital cannot be analyzed exclusively through a list of indicators that quantify the allocation of a particular resource at a given time, but it is rather necessary to analyze the territorial allocation in its temporal becoming in terms of quantity and quality.

According to Safonte and Brunori ${ }^{15}$ the dimensions of rural territoriality, and, consequently, of the rural capital, constitute and reconstitute themselves as resources only if and when they are recognized, interpreted, and used by a given community. In this sense, the rural area has a double meaning: it is consisting of objective dimensions, that are its properties and characteristics, and by subjective dimensions that define instead the value and the meaning assigned by the community at a local level. This implies a cognitive alternative to the traditional functional approach, in which prevail the deterministic cause-effect relationships that, in the new setting, they must leave the field to more complex relationships, based on how economic agents interact and perceive their reality ${ }^{15}$.

In this context, a first logical path in the analysis of the environmental heritage concept and of the relationship among renewable sources and territory at rural level necessarily passes from the studies on rurality and, in particular, from the consideration of rural problems and the corresponding image that has spread in the social sciences.

The rural can be considered the place to meet and overlap of material flows and intangible assets ranging from traditional flow of raw materials and agro-food products to the economic and financial capitals, to culture, to employment, to the symbolic representation of man and nature. The existence of different constellations of networks is the basis of the dynamics of differentiation of rural areas and ensures that the rurality can no longer be defined in terms of simple dichotomy urban-rural. In this regard, van der Ploeg ${ }^{47}$ identifies the essence of rural life in what he defines as the ability of production and reproduction of living nature, because the rural is the place of co-production between man and nature and expression space-time of this process ${ }^{48,49,50}$.

The goal becomes to understand how the territories will participate in this process; the territory is no longer assumed to be identifiable and definable, but it is to be understood as a social construction, which derives from the 
interaction between the actors and the components (tangible and intangible) of the place and those who founded the local identity as a function of the collective action of individuals ${ }^{51,52,53,54}$.

\section{Methodology}

The research operationally saw the application of the model to a rural area falling within the center of Sicily, limited to the area shown in Fig 1.

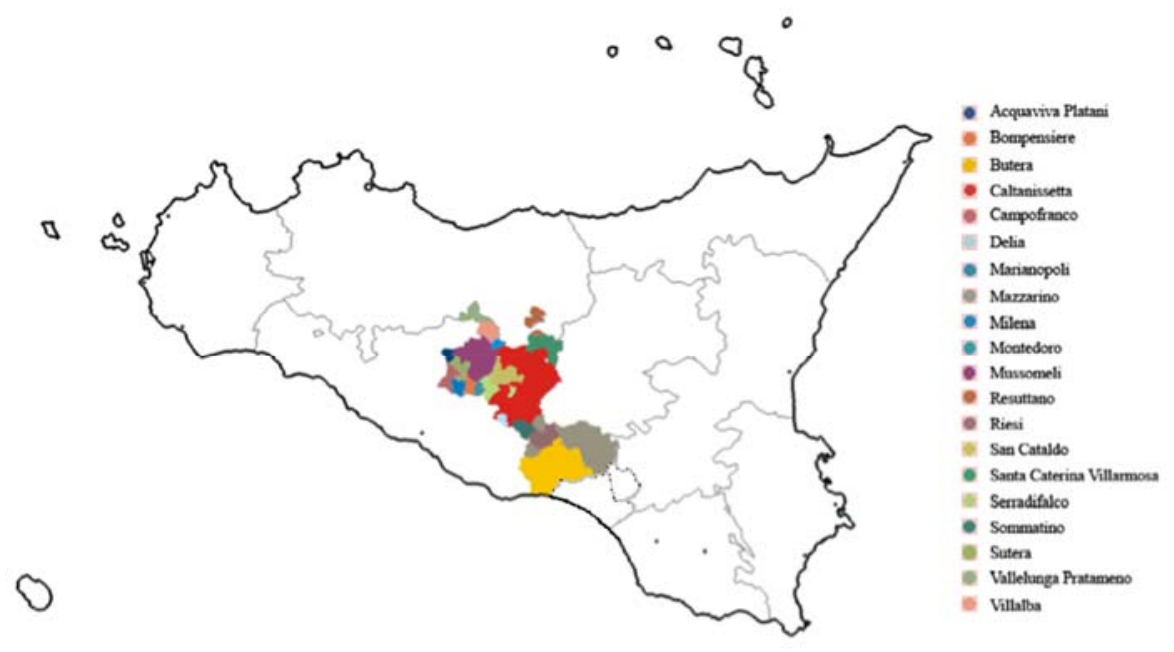

Fig. 1. Rural area under study (our processing).

For this area, in fact (Fig. 2), there is no difference between the various urban-rural classification criteria ${ }^{31,33,55,56}$.

This area - connoted, by many empirical studies, as territorial drift $s^{57}$ - has a low demographic density with no little problems of employment and income distribution, characterized by a significant infrastructure deficit and by a rural context indicating a strong presence of agriculture, in which the historical and artistic heritage is little known, whose cultural activities are aimed at enhancement of traditions, of history and local identity.

Considering that an activity of strategic analysis directed to a circumscribed territorial system cannot be separated from the collection and from the comparison of cognitive elements owned exclusively by the various local active subjects, the methodological approach - which followed the capabilities approach of $\operatorname{Sen}^{18,19}$ and the Grounded Theory of Glaser and Strauss ${ }^{58,59}$ - provides that the assessment of environmental heritage perceived level is the final step of a process that begins from the recognition, at the local level, of the tangible and intangible dimensions of that we define as rural capital.

It is the set of dimensions that involve the combination of components and of the tangible and intangible peculiarities of these territorial contexts that make up the total assets.

According to this approach, the rural area is no longer objectively identifiable and definable, but it is to be understood as a very social construction, derived from the interaction among the individuals/societies and environments. 
Classification of rural areas of Italy accordin to the National Strategic Plan (NSP) 2007-2013

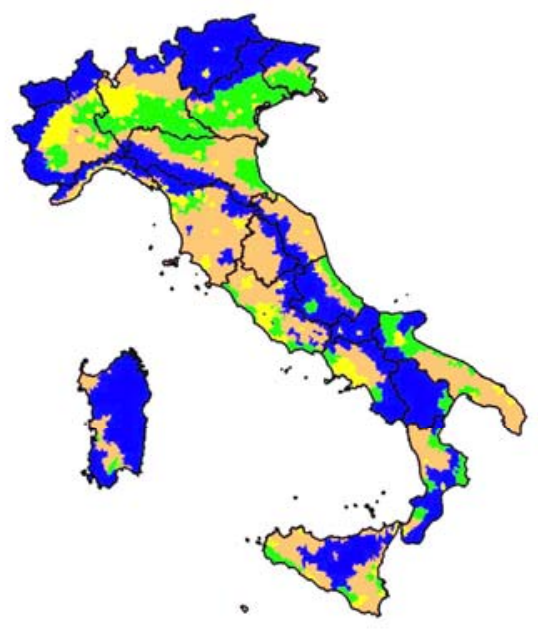

Classification of rural areas of Sicily under the Rural Development Programme 2007-2013

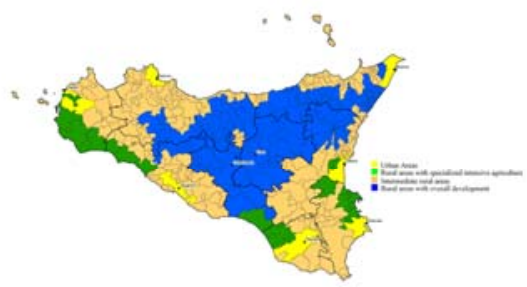

Demarcation of less-favored farming areas in Sicily under tha EEC Directive 268/75

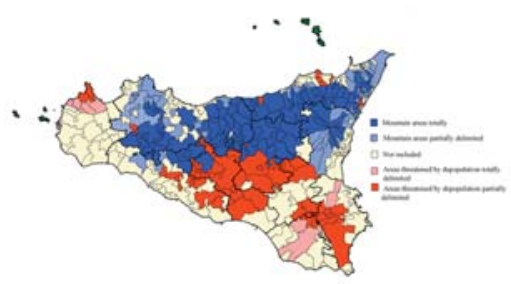

Fig. 2. Classification of rural area in Italy and Sicily (our processing)

This analysis is performed both through the examination of identified benchmark indicators, and through the observation of various phenomena, directly experienced by rural residents, detected by sample surveys that, by using a complex sampling design, allow more accurate estimates, modelled on the contexts (Fig. 3).

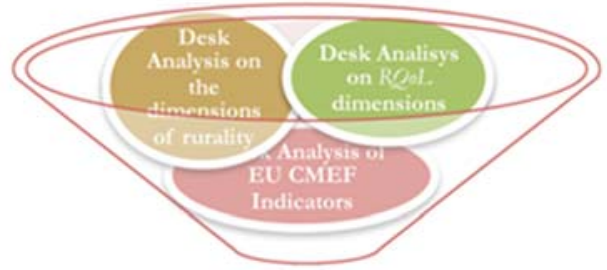

Comparison, reclassification of the identified

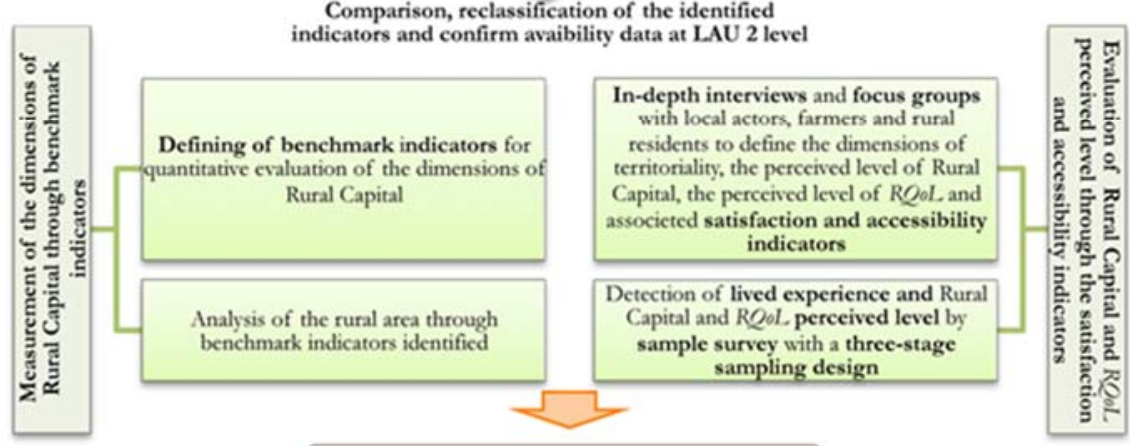

RURAL CAPITAL ANALYSIS

Fig.3. Operative articulation of the followed methodology (our processing) 
A representative sample of rural residents is constructed, starting from the identification of the respondents through a specific means, the inversely proportional fixed stratified sampling plane, therefore applying, in all the strata, the same sampling fraction. This technique, by taking into account the variables of the rural realities (quantitative and qualitative, related to territorial characters, population distribution, voting stations areas) selects the sample units by using a technique which, in the literature, is used just to deepen the knowledge of small layers of the population.

In particular, to ensure the representativeness of those residing in the countryside, we used a three-stage complex sampling design, to contain the sample size and achieve more accurate estimates.

The sampling unit of first stage is given by the municipality. Considering that all municipalities located in the area are classified as intermediate rural area ${ }^{55}$, to sample among these the municipality with rural predominate characteristics, the list was previously divided into layers according to the variables: demographic size, urbanization index and rurality index.

The sampling unit of second stage is given by polling section, from these, the names to be interviewed are subsequently extracted, the number of which, respectively, was calculated in proportion to the population distribution.

In this regard, it should be noted that we define rural residents all those that are residing and living in the territory under study, regardless of the typology of sub-regional area of origin (urban, peri-urban or peripheral area, rural area properly said or countryside).

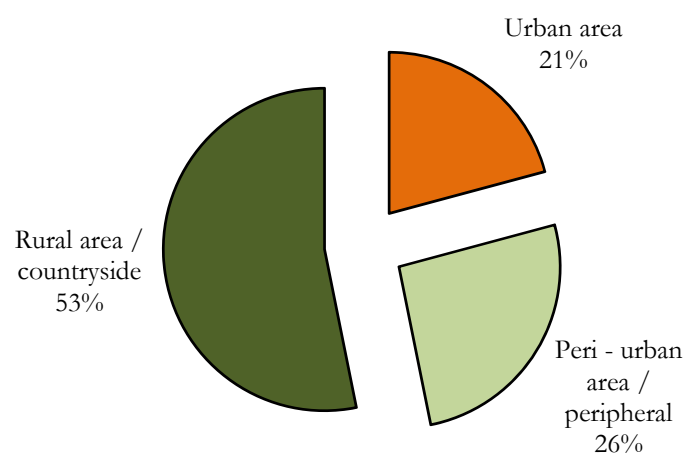

Fig. 4 Sample distribution according to the typology of geographical residence area (our processing of data collected through quantitative survey)

All interviews, carried out face to face during the second quarter of 2016, at the respondent's home, followed a structured questionnaire consisting of two sections.

The objective of first section is to determine the relative importance of each dimension within which the environmental heritage can be broken down.

The second section concerns the attitude towards the rural area, as well as aspects related to rural lived and rural behaviour. The socio-demographic data section closes the questionnaire.

All these results are integrated by a multi-case study carried out by a qualitative survey detected both through desk analysis and in field observation, and through in-depth interviews with stakeholders and focus groups with local actors, all asked to assess in a participative way.

\section{Results}

The theoretical framework and the methodological approach has allowed the understanding of the different dimensions of territoriality, allowing, on the one hand, to draw up a taxonomy of the different dimensions, which are shown in Fig. 5, and, on the other, to identify a mixed indicators system (benchmarks indicators available at LAU2 level and satisfaction and accessibility indicators detected locally) able to analytically describe the rural capital dimensions at the local level (Fig. 6). 


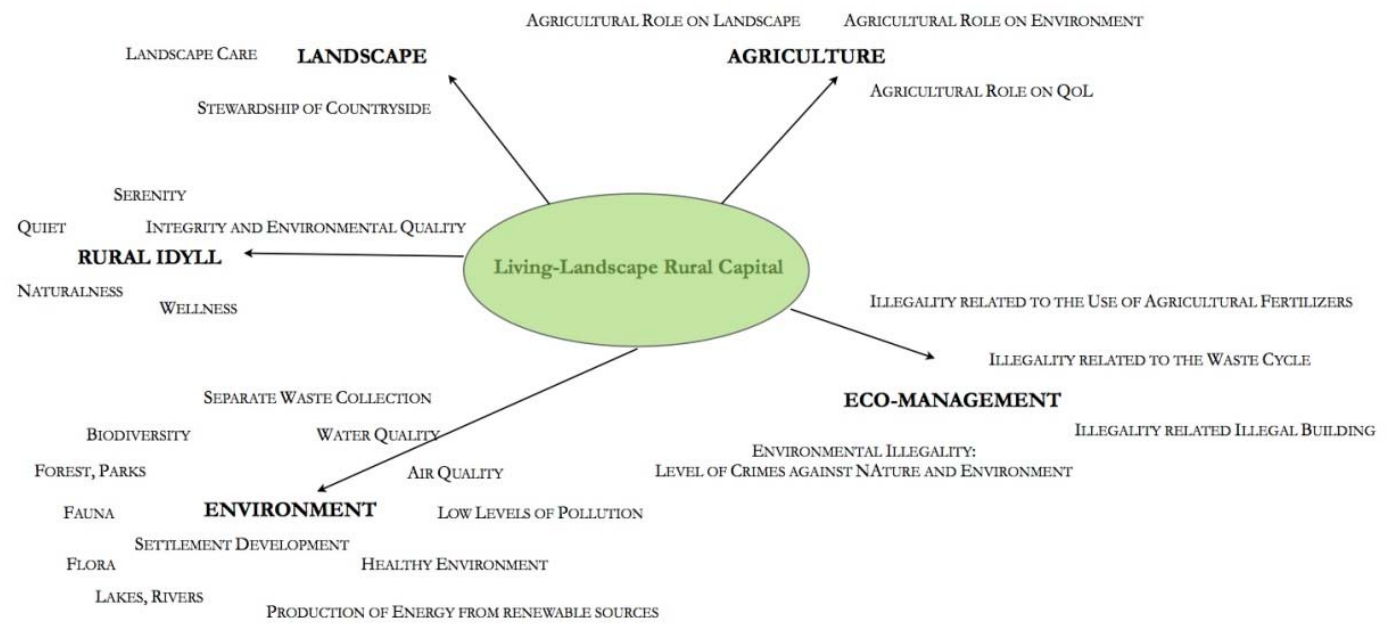

Fig. 5 Living Landscape Rural Capital dimensions (Our processing of data collected through quantitative and qualitative survey)

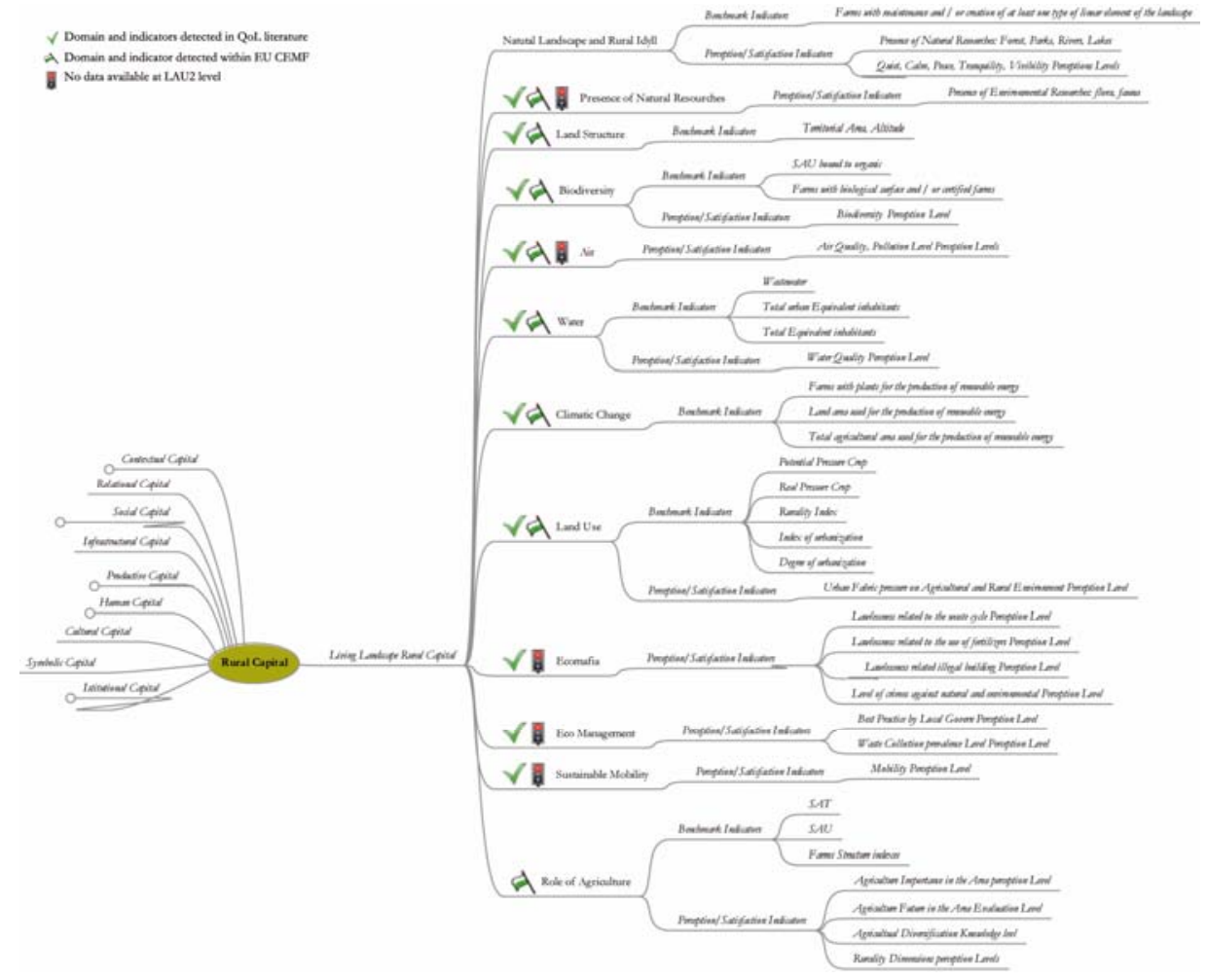

Fig. 6 Benchmark indicators and used satisfaction/perception indicators (Our processing of data collected through quant. and qual. survey).

The results show that the concept of rural capital and its dimensions are well suited to the assessment of perceived levels of rural environmental heritage. In fact, at the local level, the life environment assumes absolute centrality. It is perceived in its procedural long-term dimension, as a result of the meeting between the tangible and 
intangible elements of rural capital as a whole, in which the specific dimensions of this territorial typology play a crucial role.

They consist of: a) living-landscape rural capital - resulting from the interaction between the actors, who insist on the area, and the landscape and environmental assets and in which the role played by the primary sector is an essential element, and b) rural socio-relational goods, which, in rural areas, take on specific and pervasive forms (Fig. 7).

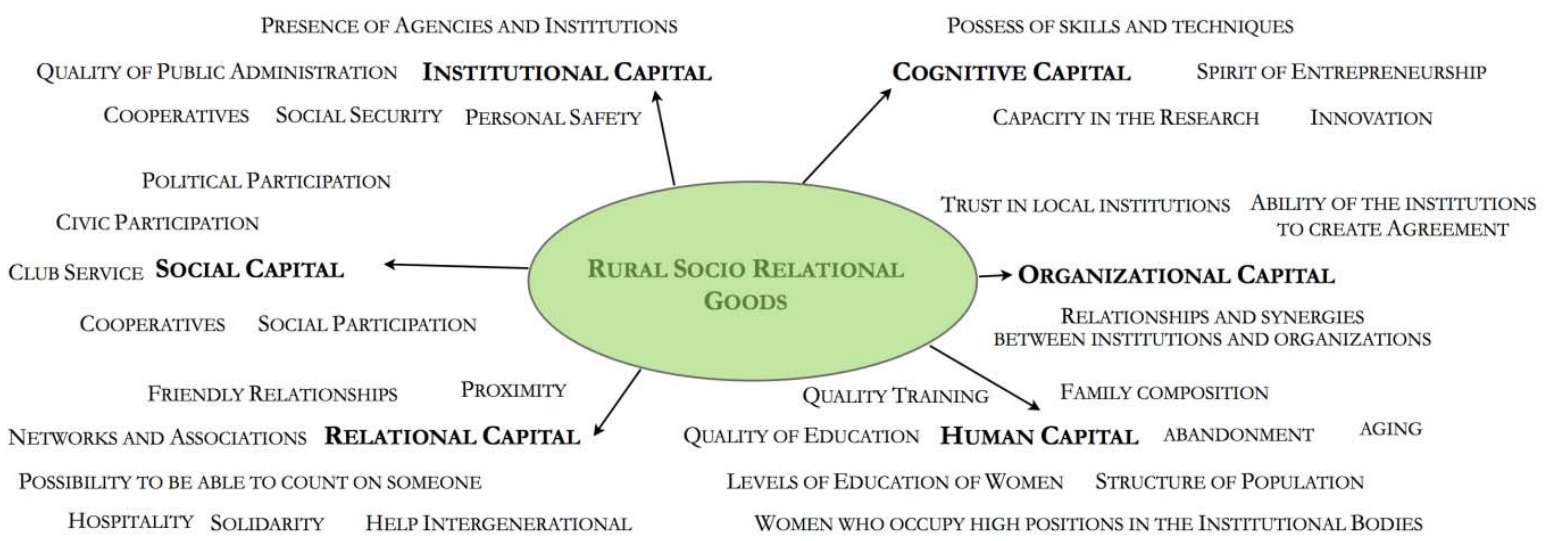

Fig. 7 Rural socio relational goods dimensions (Our processing of data collected through quantitative and qualitative survey)

In the overall analysis of the local rural capital, the environmental heritage turns out to be one of the main strengths of the area; in fact, the environmental and landscape issues play a strategic role in the overall HE assessment of the area. The environment offers a good variety and richness of natural resources.

The rural residents satisfaction level on environmental issues is high, as well as for the natural landscape; the environmental quality assessment, measured by the assignment of a judgment on the presence of a healthy environment and low levels of pollution, is excellent. Alternatively, there was a not quite positive evaluation, on the one hand, to issues relating to the development of settlements, valued by residents through an assessment of the pressure that the urban buildings exercise on agriculture and rural environment, and, on the other, to all issues related to the production of energy from renewable source, environmental legality and eco-management level.

To assess the role that agriculture plays on the definition and perception that rural residents have about the environmental heritage of their residence area, we investigated the relationship between the polyvalence of agricultural activity and the environmental heritage perceived level, examining the capacity response of the primary sector towards the territorial attractiveness, guaranteed only if the environmental heritage level is generally perceived as high.

To this end, it was asked to the rural residents to assign a score (on a scale from 0 to 10 ) to certain components (Fig. 9) with respect to what these will help to create a belonging sense towards their area of residence.

The multifunctional dominant perception of rural expressed by residents in peri-urban areas is reflected in the results of Tab. 1, which analyses the knowledge of firms that practice new forms of agriculture and new forms of energy production.

It is clear that presence and knowledge of rural multifunctional activities and of new forms of energy production, is more widespread in the countryside and that level of knowledge decreases moving from the rural to the urban.

Focusing on the role, on the position and the contribution that the primary sector provides on environmental heritage of the rural territory under study, the majority of respondents expressed a favorable opinion on the role of agriculture and the key elements of rurality as factors able to contribute to the environmental heritage perceived level at local level. 


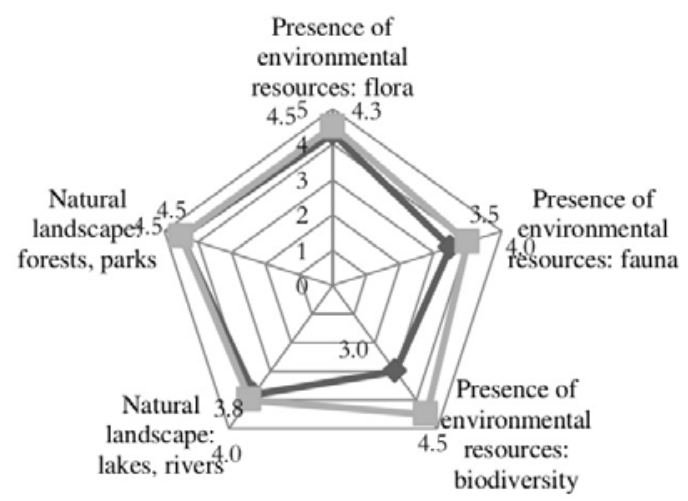

$\longrightarrow$ Satisfaction indicators - Accessibility indicators

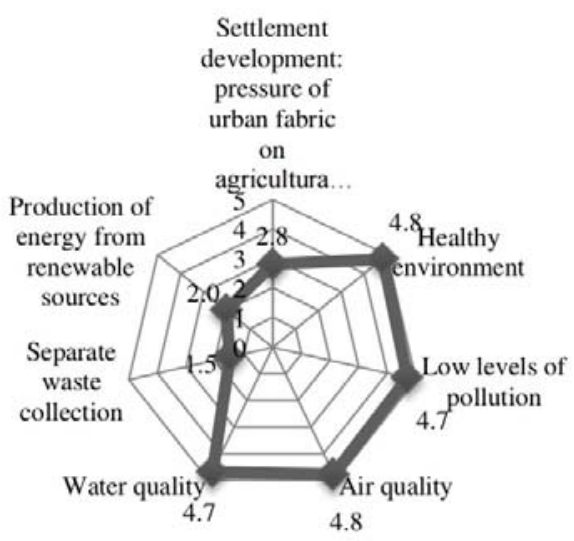

$\longrightarrow$ Satisfaction indicators

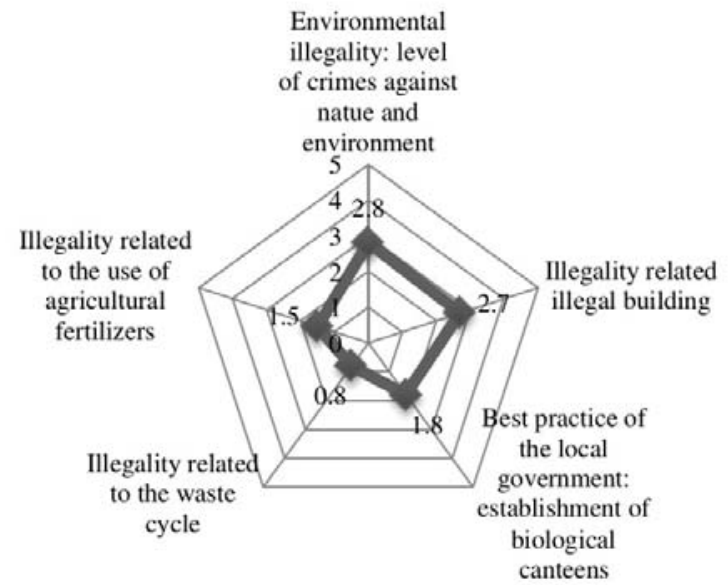

$\longrightarrow$ Satisfaction indicators

Fig. 8 Profile of the environmental heritage according to rural residents (Our processing of data collected through quantitative survey)

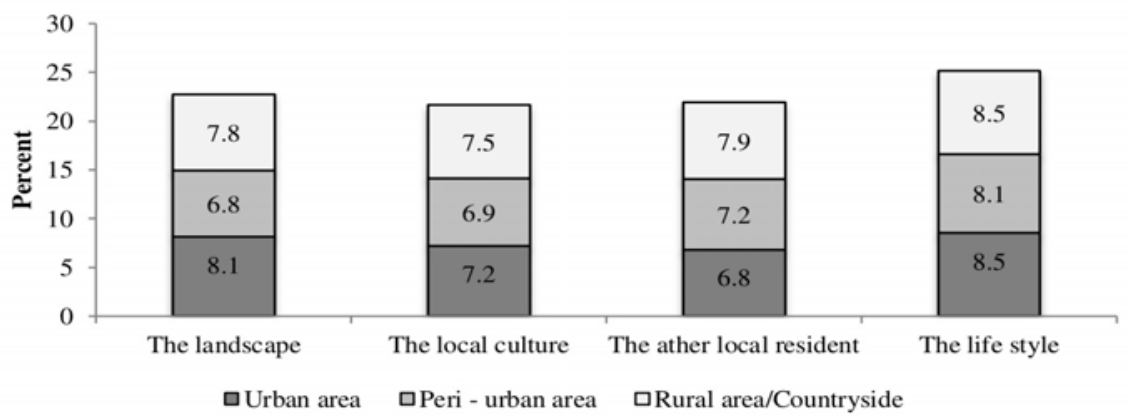

Fig. 9 Satisfaction indicators on the dimensions of rurality according to the typologies of areas of residence (mean scores; evaluations expressed through score on a scale from 1 to 10 - Our processing of data collected through quantitative survey) 
Tab. 1 Residents who have direct knowledge of firms, operating in their area, practicing new forms of agriculture (multiple answers; per cent)

\begin{tabular}{lccc}
\hline New forms of agriculture & Urban area & Peri-urban area & Rural area/Countryside \\
\hline Retail sales in farm & 12,3 & 19,7 & 45,6 \\
Landscape maintenance and & 3,5 & 3,8 & 52,9 \\
management & & & \\
Farm holidays & 90,3 & 99,8 & 100 \\
Canteens and hospitals supplies & 1,1 & 1,8 & 1,9 \\
New forms of energy production & $\mathbf{0 , 9}$ & $\mathbf{2 , 5}$ & $\mathbf{8 , 3}$ \\
Do not know / No answer & 3,8 & 2,3 & 0,5 \\
\hline
\end{tabular}

Our processing of data collected through quantitative survey

To understand which is this level in the area under study and what are the determinants dimensions, we have measured:

1. The overall environmental heritage satisfaction level, which turns out to be equal to 4,52 ;

2. The satisfaction level on the territorial endowment dimensions that influence overall environmental heritage and the level of importance that these dimensions have on the environmental heritage of the residence area.

To define a first interpretative framework, the identified indicators were considered priorities when taking high levels of importance in conjunction with low levels of satisfaction.

The identification of indicators with these characteristics allows the decision maker to highlight the main improvement areas directing policy interventions towards the dimensions considered most important and, at the same time, less satisfactory by rural residents.

The analysis of results allowed us also to draw some operational considerations.

Firstly, the results show that the concept of rural capital and its dimensions (included the landscape-life environment one) are well suited to the assessment of perceived levels of environmental heritage. In fact, at the local level, the life environment assumes absolute centrality. It is perceived in its procedural long-term dimension, resulting from the meeting between the tangible and intangible elements of rural capital as a whole, in which the specific dimensions of this territorial typology play a crucial role.

The results show that the environmental heritage perceived level increases with increasing consistency between the dimensions concerning landscape, environmental, social, institutional and cultural issues.

Secondly, the proposed approach has allowed us to disclose the inadequacy of current methods of detection and investigation, and thus demonstrates how the knowledge of rural capital contributes to determine the qualitative economical capabilities of a rural local system as being crucial for its ability to foster learning processes.

The active involvement of residents, stakeholders and local actors, within each of the sampled municipalities, has allowed the activation of democratic processes of partnership and collective social learning and has also contributed to the construction of new forms of civic accountability until then unknown. The self-consciousness also encouraged and facilitated the definition of an organizational decision-making and policy actions management in line with the development model based on the idea of territorial governance, defined as what makes it possible to the rural area to behave and act as a collective actor and through which re-generate a shared understanding of local opportunities.

The lack of awareness about the importance of the dynamics of participation and sharing makes that the participatory dimension is often trivialized, relegated to liturgical conducts, isolated in the context of local consultation, which in itself is not able to produce adequate results either in terms of sharing of knowledge, nor in terms of developing processes of collective intelligence or, in other words, it's not capable of leading to changes in the relational structure of the system itself.

If the capability to generate spatial development derives essentially from the ability to mobilize local stakeholders in the planning, organization and exchange of information flows, often the dynamics of rural marginalization are able to distort the policy processes involvement and the activities of local communities are limited to simple consultation rather than being related to an effective empowerment.

Following this perspective, the methodology has allowed to make the process of reorganization of the visions as aimed to real participative project planning strategies for sharing knowledge before and for intervention after, allowing, on the one hand, to re-establish the principles and forms of management of the rural area as a common 
good, and, secondly, to develop those forms of mutual recognition of belonging to the place as able to promote the political and cultural change toward a growing sense of place and active citizenship.

Moving from the methodological to the theoretical level, whether to regulate a local system it is necessary to understand the mechanisms that govern the processes of self-eco-organization that gives rise to the evolutionary path that the rural areas run through, the evidence showed that it is impossible not to assign a role to the learning of all local actors, including the decision makers, and to their ability to think (intelligence) and to formulate policy actions. In this sense, these forms of collective learning in rural and inner areas, necessary for decision-making processes of rural development, able to be translated into regulatory policies, impose upon the decision maker to revise the strategic choices that take into account the outcomes of the development strategies of individual actors at the local level.

That being so, it is therefore possible to identify a development path in which the focus is not just the capacity and strength of the economic fabric of generating income, but appears important to consider other forms of tools, different from those traditionally intended, in which it can integrate environmental heritage.

The presented model is designed to suggest a reading key useful to systematize similar case histories and move inside the complexity of relationship between renewable energy sources and territory, both in a methodological interpretative perspective and operational, serving as a reference for future applications and empirical studies.

In this regard, in order to verify the reproducibility of the exposed model and the opportunity that this gives rise to new models of planning in rural areas, the research group has adopted the approach of integrated planning based on rural socio relational goods for redevelopment of Borgo Schirò.

\section{An integrated relational approach to rural regeneration: a case study}

The Agricultural Development Agency ${ }^{60}$ of the Region of Sicily has been involved in the redevelopment of Borgo Schirò (Fig. 10), a small rural center - located in Monreale in the countryside of the highlands south of Palermo, in the western part of the island - built in the 1940s during the Mussolini government, through the national policy of countryside's urbanization, in order to maximize all the national productive resources like as contrast to the Atlantic alliance economic embargo during World War II ${ }^{61,62,63,64}$.

The research team has worked on the transdisciplinary analysis for social and economic regeneration of the village. The project ${ }^{65}$ aims to create the preconditions for the effectiveness and durability of the requalification through the recovery of abandoned architectures, proposing new technological features to satisfy the needs of potential residents with respect to the urban level living standards.

The project plans to make fully independent the local housing system from the point of view: a) energy consumption; b) treatment of waste; and c) water. Dozens of rural villages abandoned but still in public ownership along with large areas of arable land are in Sicily. Therefore, the project can be loanable in all the Sicilian countryside where there are both the rural villages that previous rural settlements dating back to the Arab period as well as in many peripheral areas of the Sicilian agro-town built from the end of the sixteenth century ${ }^{66}$.

The work starts from the assumption that the city planning necessarily involves the planning of its suburban territory. In general, the rural areas (first abandoned and then regenerated by human presence) strengthen the relations between the various parts/systems which together make up the territorial landscape understood as a new town in extension ${ }^{67}$. In particular, with reference to the strong territorial disequilibria of Sicily, the design idea actualizes a popular approach of land use planning already proposed to contrast the separation of urbanized and developed coast from the rural hinterland that is being abandoned ${ }^{68}$ (Fig.11).

The biasing policies of industrial production in the coastal areas of the $60 \mathrm{~s}$ induced the choice to concentrate in the same territorial areas the production of energy through the massive use of highly polluting fuel resources. However, previously, the majority of the population - at the progressive decline of the primary sector for the benefit of the creation of an urban tertiary dependent on the public sector - had already moved on the coasts. The whole energy production and industrial production was concentrated on the coasts together with the urban densification in the second post-war period ${ }^{69}$. The project intends to explore the possibilities to reverse these 
phenomena regional imbalance by focusing on the design of small-scale interventions centered on the voluntariness of the choices (free participation) and on autonomy of investments guaranteed by technological progress taking place, both in the production rural (Smart land, Smart farming) and in communicative-relational context (smart community) (Fig. 12).
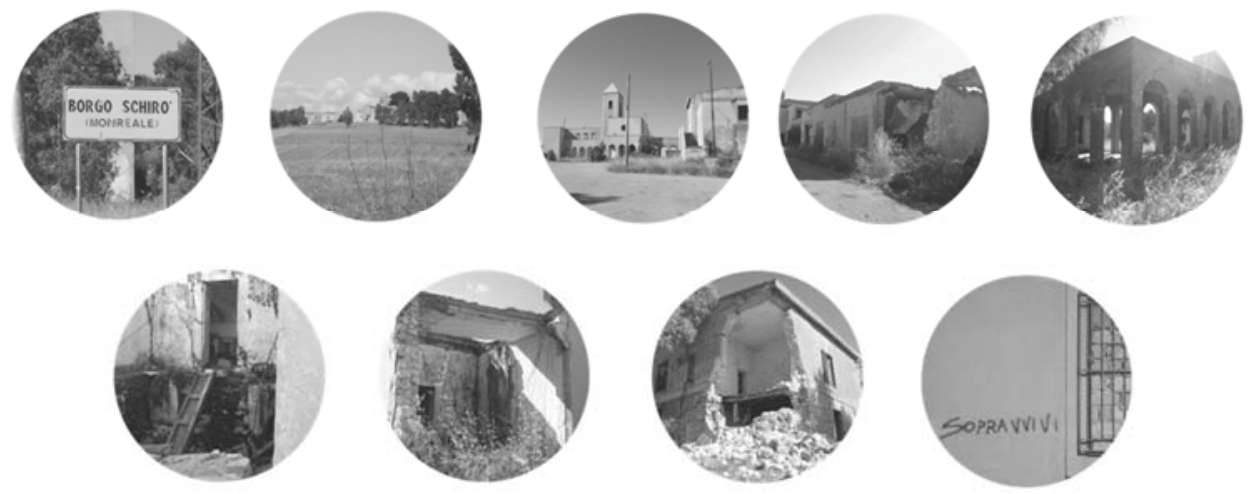

Fig.10. The actual situation of the fabrics of Borgo Schirò
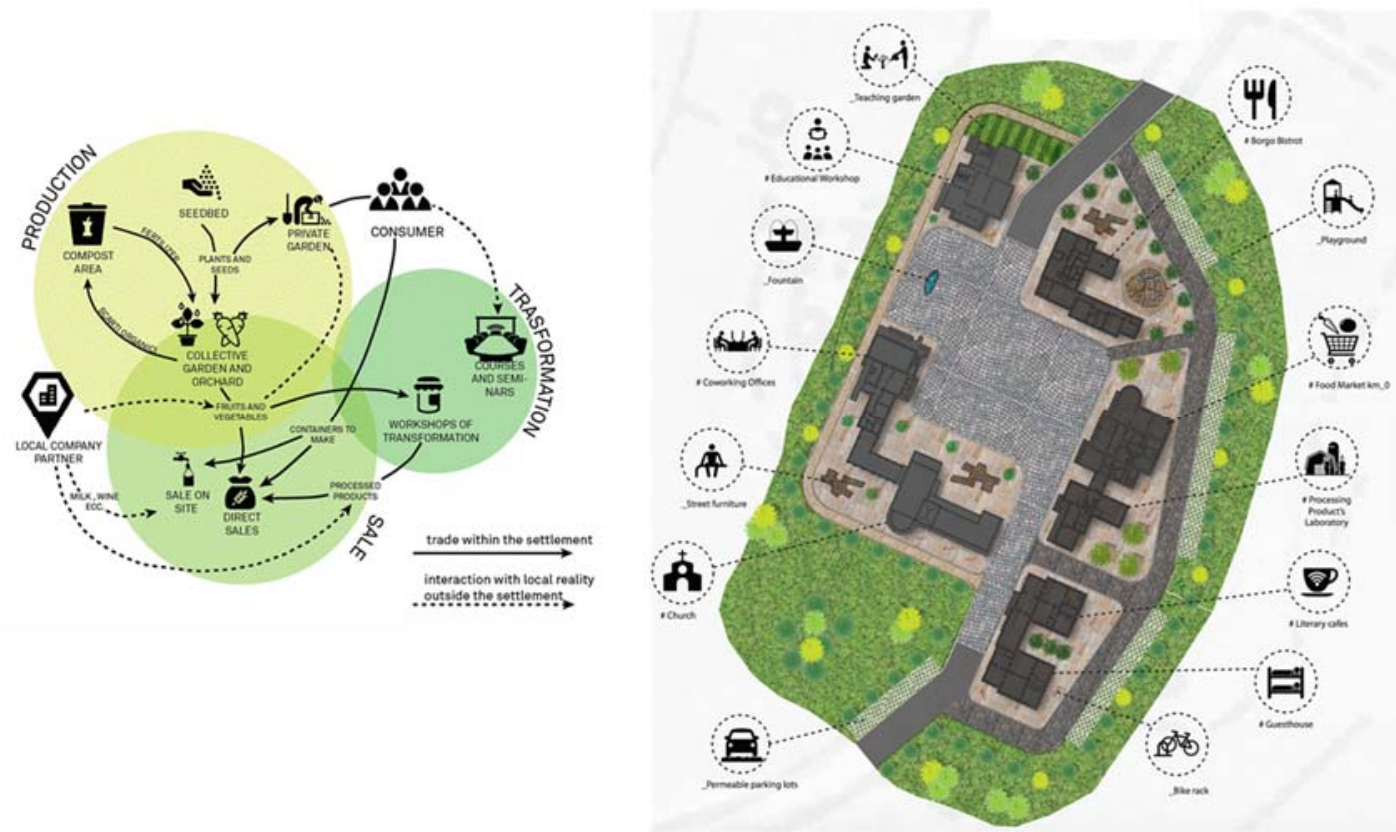

Fig.11. The Farming chain and masterplan of Borgo Schirò proposal

The project to recover Borgo Schirò is replicable in all rural principals of the Sicilian countryside and, in full environmental sustainability and relational key; it can be a highly effective regional rebalancing policy that requires an innovative governance based on participation and on the ability of regional government to directly engage the settled communities. Such governance should involve the current push to the return to the countryside by the urban populations. 


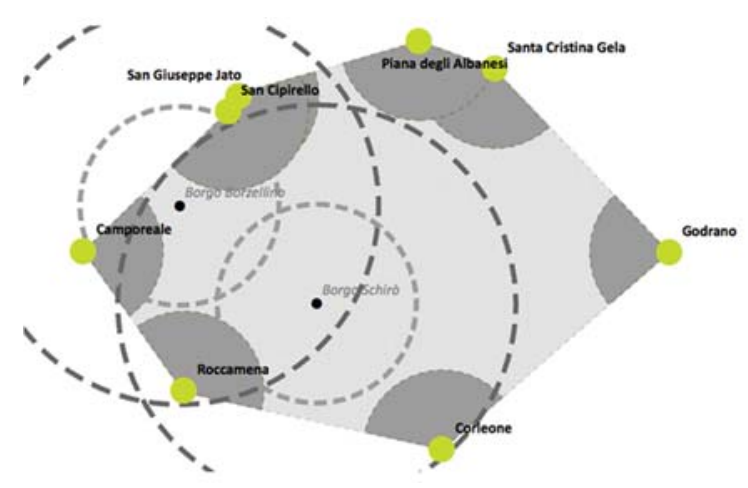

Fig.12. The localization of Borgo at the center of principal agro-town

This project is in operational terms a model for implementation of policies and governance of the Sicilian Region in order to properly utilize the resources of the 2014-2020 Structural Funds, of the Rural Development Programme and, in particular, of the National Strategy for Inner Areas, proving that virtuous examples for energy, environmental, cultural and social regeneration can be obtained, recovering the territorial heritage abandoned in rural areas. For that to happen it is necessary to activate urban/rural regeneration processes in which the rural capital is reconnected through the implementation of relational and territorialist approaches.

\section{Discussion}

About the questions posed, the results of the study shows that, at the local level, the concept of territory, perceived in its procedural dimension of long duration, takes absolute centrality.

Therefore it will be the privileged tool to reorient the development process and/or the process of economic and social balance, as demand for a local project that get back into the game the resources, vocations and the territorial potential that are still relegated to marginal conditions.

In this way, the concept of environmental heritage could become the basis for a future design of the production of wealth based on optimization of the environmental heritage itself.

These reflections enable us to go further, allowing to say, firstly, that the territorial capital and the environmental heritage can be explored as "political objects", and secondly, that renewable energy sources can in some way contribute to the achievement of territorial sustainability objectives at the local level.

If on one hand, in fact, their valorization can take place both in a global perspective, exogenous with respect to local contexts, and in a more territorialized perspective, on the other hand, the wealth of the socio-economic component must be further strengthened to ensure that the endogenous initiative of local actors assume a more central role, and the complexity of the ecosystemic component is taken into account to recognize and avoid the various environmental impacts generated by the entire energy chain. Between these extremes, there are numerous conceptual gradations ranging from less sustainable attitudes towards resources (environmental, energetic and relational) of the territory to approaches characterized by a strong localism but that doesn't sufficiently take into account the complexity of the energy problem.

The methodology leaves out the need for a new approach to rural areas, which is defined precisely relational and territorialist, showing how the raising of rural environmental heritage and its relationship with renewable sources is able to return a central role to the gradual rapprochement of the decision-making centers to control and govern the local communities. Only if it were recovered, at all levels of governance, the capacity of an overall strategic vision based on the reconstruction of knowledge, hinged on the reconstruction of a culture and a thought of the territory. Such an approach should be followed by policy actions able to enhance the territorial endowment, integrating the necessary cultural, environmental, economic and social policies. It represents the key challenge for the innovation of public policies. 


\section{References}

1. IPCC. Climate change 2007. Synthesis report. In Intergovernmental Panel on Climate Change. Geneva; 2007.

2. Dincer I. Environmental impacts of energy. Energy Policy 1999, 27. pp. 845-854.

3. Dincer I. Renewable energy and sustainable development: a crucial review. Renewable and Sustainable Energy Reviews 2000, 4. p. 157-175.

4. Cavallaro V. \& Dansero E. Sustainable development: global or local? Geojournal 1998, 45. p. 33-40.

5. Zuindeau B. Spatial approach to sustainable development: challenges for equity and efficacy. Regional Studies 2006, 40, 5. p. 459470.

6. Bagliani M., Dansero E. Lo sviluppo sostenibile tra locale e globale: una prospettiva territoriale. In Bulsei GL. editor, Le sfide della sostenibilità. Risorse ambientali, qualità sociale, partecipazione pubblica. Roma: Aracne; 2010.

7. Elliot D. Renewable energy and sustainable futures. Futures 2000, 32. p. 261-274.

8. Kellett J. Community-based energy policy: a practical approach to carbon reduction. J Environmental Planning and Management 2007, 50, 3. p. 381-396.

9. Sheer, H. Solar city: reconnecting energy generation and use to the technical and social logic of solar energy. In Droege P., Urban energy transition. London: Elsevier; 2008. p. 17-26.

10. Krueger R., Agyeman J. Sustainability schizophrenia or actually existing sustainabilities? toward a broader understanding of the politics and promise of local sustainability in the US. Geoforum 2005, 36. p. 410-417.

11. Puttilli M. Geografia delle fonti rinnovabili. Energia e territorio per un'ecoristrutturazione della società. Milano: FrancoAngeli; 2014.

12. Riva Sanseverino E., Riva Sanseverino R. \& Vaccaro V. editors. Smart Cities Atlas. Western and Eastern Intelligent Communities. Dordrecht: Springer; 2017.

13. Concilio G. \& Rizzo F. editors, Human Smart Cities. Rethinking the Interplay between Design and Planning, Dordrecht: Springer; 2016.

14. Pallante M. La decrescita felice. Roma: Editori Riuniti; 2005.

15. Safonte GF., Brunori G. Multiple Rural Identities. In Rural Resilience and Vulnerability: the rural as locus of solidarity and conflict in times of crisis. Laboratorio di studi rurali, Pisa (Italy), Firenze, 29 July - 1 August 2013; Firenze; 2013.

16. Hann de L. Globalization, Localization and Sustainable Livelhoods. Sociologia Ruralis 2000; 40,3: 339-365.

17. Knuttson P. The Sustainable Livelihoods Approach: A Framework for Knowledge Integration Assessment, Human Ecology Review $2006,13,1$.

18. Sen AK. Capability and Well-Being. In Nussbaum M., Sen A. editors, The Quality of Life. Oxford: Clarendon Press; 1993. 18. Sen A. K. 1993. p. 31- 53.

19. Sen AK. Well-Being, Capability and Public Policy, Giornale Degli Economisti e Annali di Economia 1994; 53: $333-347$.

20. Marsden T.K., The condition of rural sustainability, Royal Van Gorcum, Assen, 2003.

21. Kaljonen M. Co-construction of agency and environmental management. The case of agri-environmental policy implementation at Finnish farms, Journal of Rural Studies 2006, 22 (2): 205-216.

22. Murdoch J., Marsden T., Banks J., Quality, nature, and embeddedness: some theoretical considerations in the context of the food sector. Economic Geography, 2000, 76 (2): 107-125.

23. Renting H., Marsden T.K., Banks J., Understanding alternative food networks: exploring the role of short food supply chains in rural development, Environment e Planning, 2003, 35: 393-411

24. Ray C., Towards a meta-framework of endogenous development: repertoires, paths, democracy e rights. Sociologia ruralis, 1999, 39, 4: $522-537$

25. Ploeg van der J.D., Renting H., Brunori G., Knickel K., Mannion J., Marsden T., de Roest K., Sevilla-Guzman E. e Ventura F., Rural development: from practices e policies towards theory. Sociologia Ruralis, 2000, 40(4): 391-408.

26. DuPuis E.M., Goodman D., Harrison, J. (2006), Between the local e the global: confronting complexity in the contemporary agri-food sector research. Rural Sociology e Development, 2006, 12: 241-268

27. Latour B. Reassembling the social: an introduction to actor-networktheory. New York : Oxford University Press; 2005.

28. Brunori G. Sistemi agricoli territoriali e competitività. In: Casati D, editor, La competitività dei sistemi agricoli italiani, Atti del XXXVI Convegno di Studi, Milano, 9 - 11 Settembre 1999. Milano: FrancoAngeli; 2003.

29. Brunori G. Post-rural processes in wealthy rural areas: hybrid networks and symbolic capital. In Mursden TK, Murdoch J, editors. Between the Local and the Global: Confronting Complexity of the Agri-Food Sector. Research in Rural Sociology and Development 2006; 12:121-145.

30. Safonte G.F., Brunori G. Rural Capital and Rural Well-Being. A Theoretical and Methodological Framework for the Measurement of Rural Quality of Life at local Level. In Measuring Progress at Local Level. Pisa: University Press, 2013: 145-146.

31. OECD. Territorial Outlook. Paris: OECD Publication; 2001.

32. OECD. The New Rural Paradigm. Policies and Governance, OECD, Paris; 2006.

33. European Commission - EC, Community strategic guidelines for Rural development (Programming period 2007-2013), COM(2005) $304,5 / 07 / 2005$.

34. Ventura F., Milone P. editors. La Nuova Agricoltura. Impatto socio - economico delle politiche di sviluppo rurale. Milano: Franco Angeli; 2004. 
35. Ventura F., Milone P., Traiettorie di sviluppo. Il sostegno a modelli di sviluppo endogeno: dall'esperienza del distretto viti-vinicolo di Montefalco alla valorizzazione dell'area della Valnerina, AMP Edizioni, Perugia; 2005.

36. Ventura F., Milone P., Berti G., Brunori G. Some notes on the identification of rural webs, in Milone P., Ventura F. editors, Networking the Rural. The future of green regions in Europe, Van Goncum. NL. 2010.

37. Governa F. Territorio e territorialità fra risorse e valori, in Bertoncin M., Pase A. (2006) (a cura di), Il territorio non è un asino. Voci di attori deboli, FrancoAngeli, Milano; 2006.

38. Svendsen G.L.H., Sørensen J.F.L., There's more to the picture than meets the eye: Measuring tangible and intangible capital in two marginal communities in rural Denmark, Journal of Rural Studies, 2007, (23)4.

39. Sassi M. Modello di sviluppo rurale e nuove sfide di programmazione territoriale, Economia e Diritto Agroalimentare, XIII, $2008,1$.

40. Camagni R. Towards a Concept of Territorial Capital, Paper presented to Joint Congress of the European Regional Science Association (47th Congress) and ASRDLF (Association de Science Régionale de Langue Française, 44th Congress), PARIS, 2007, August 29th - September 2nd.

41. Bourdieu P. The forms of capital, in Richardson JG (ed), The Handbook of Theory: Research for the Sociology of Education, Greenwood Press. New York, Greenwood Press; 1986.

42. Bourdieu P. Ragioni Pratiche, Il Mulino, Bologna; 1995.

43. Countryside Agency. The state of the countryside. Cheltenham. Countryside Agency; 2003: 43. Available on website: http://www.countryside.gov.uk (accessed on March $4^{\text {th }}$ 2017).

44. Garrod B., Wornell, R., Youell R. Re-conceptualizing rural resources as countryside capital: The case of rural tourism. J Rural Studies 2006; 22. p. 117-128.

45. Mitchell CJA. Entrepreneurialism, commodification and creative destruction: A model of post-modern community development. $J$ Rural Studies 1998; 14,3. p. 273-286.

46. McClinchey K.A., Carmichael B.A. Countryside capital, changing rural landscape and rural tourism implication in Mennonite country, J Rural and Community Development 2010; 5,1-2. p. 178-199.

47. Ploeg JD. van der. On rurality, rural development and rural sociology. In De Haan H., N. Long, editors. Images and realities of rural life., Assen: Van Gorcum; 1997.

48. Safonte GF. Rural Happiness, Rural Quality of Life and Self-Consciousness. A Multi - Case Study. In Happiness. International Institute Advanced Studies. Barden - Barden (Germany), July $29^{\text {th }} \sim$ August $2^{\text {nd }} 2013 ; 2$. p. 33-39

49. Safonte GF. Earth and Environment. The territorialist approach and the quality of life in rural areas. Scienze del Territorio, 2014, 2: 339-366.

50. Safonte GF, L'Approccio territorialista allo sviluppo rurale. Analisi partecipativa dei contesti rurali e qualità della vita, in AA.VV., Manuale di Progettazione Partecipata per lo Sviluppo Sostenibile dei Territori Rurali. L'esperienza di un corso di alta formazione, ETS Edizioni, Pisa, 2015.

51. Magnaghi A. Il patrimonio territoriale: un codice genetico per lo sviluppo locale autosostenibile, in A. Magnaghi (a cura di), $I l$ territorio degli abitanti: società locali e sostenibilità, Dunod, Milano, 1998.

52. Magnaghi A. Il progetto locale. Verso la coscienza di luogo, Bollati Boringhieri, Torino, 2010.

53. Magnaghi A. (eds), Il territorio bene comune, Firenze University Press, Firenze, 2012.

54. Manzini E. Relazione introduttiva, I Congresso Fondativo, SdT-Società dei Territorialisti, Firenze, 1 e 2 Dicembre 2011.

55. MIPAAF. National Strategy Plan for Rural Development. Ministero Delle Politiche Agricole, Alimentari e Forestali. Roma; 2007: www.reterurale.it.

56. European Council. DIR. 75/268/EEC, 1975 April 28th: on mountain and hill farming and farming in certain less-favoured areas.

57. Toscano M. Derive territoriali, Ed. Le Lettere, Roma, 2011.

58. Glaser BG,. Strauss AL. The discovery of grounded theory: Strategies for qualitative research New York: Aldine de Gruyter, 1967.

59. Strauss A, Corbin J. Basics of qualitative research Grounded theory procedures and techniques Newbury Park: Sage Publications, 1990.

60. ESA. Progetto di Riqualificazione dei Borghi Rurali dell'Ente di Sviluppo Agricolo. Ente di Sviluppo Agricolo. Palermo; 2009.

61. Fagiolo M. \& Madonna ML. Le città nuove del fascismo. In Studi in onore di G. C. Argan. Scandicci (Firenze): La Nuova Italia; 1994. p. 339-397.

62. Barbera P. Architettura in Sicilia tra le due guerre. Palermo: Sellerio; 2002.

63. Dufour L. Nel segno del Littorio: Città e campagne siciliane nel Ventennio. Caltanissetta: Lussografica; 2005.

64. Sessa E. La nuova immagine della città italiana nel ventennio fascista. Palermo: Flaccovio; 2014.

65. Arcuri C., Ciullo S. Cosentini A., Durante R., Faraci V., Farina F. \& Trapani F. Re-Think Borgo Schirò. Urbanpromo - 7th edition of the International Competition for Young Urban Designers and Planners Urban-promogiovani, 20th of November 2015, Triennale di Milano, Milan (Italy): http://urbanpromo.it/2015-en/urbanpromogiovani/re-think-borgo-schiro/ (accessed on March 4th 2017).

66. Giuffré M. Città nuove di Sicilia, XV-XIX secolo: Problemi, metodologia, prospettive della ricerca storica. La Sicilia occidentale. Palermo: Vittorietti; 1979.

67. Samonà G. Verso la non città. Come ricominciare. il territorio della città in estensione secondo una nuova forma di pianificazione urbanistica. In Parametro 1980; 90. p. 15-16/59.

68. Doglio C. \& Urbani L. La Fionda Sicula. Bologna: il Mulino; 1972.

69. Campione G., Grasso A., Guarrasi V. Sistemi urbani e contesti territoriali: ipotesi di regionalizzazione dello sviluppo siciliano. Regione Siciliana Direzione regionale della programmazione. Palermo; 1992. 